\title{
The Visual Practice: the Infographic as a Facilitating Tool for Learning in Medical School
}

\section{O Prático Visual: o Infográfico como Ferramenta Facilitadora do Aprendizado no Curso de Medicina}

\author{
Diêgo Andrade de Oliveira ${ }^{I}$ (iD \\ Rosângela Souza Lessa ${ }^{I}(\mathbb{D}$ \\ Suzana Cristina Silva Ribeiro ${ }^{I}$ (iD \\ Pedro Fonseca de Vasconcelos ${ }^{I}$ iD
}

\section{KEYWORDS}

- Education Medical.

- Problem-Based Learning.

- Knowledge.

- Creativity.
Introduction: In the context of medical school, the development of methodologies that stimulate the students' search for learning, autonomy and creativity are essential for medical education in Brazil. The study aims to describe the construction of infographics as a pedagogical proposal for the learning of organic human aging processes by medical students. Method: Medical students attending the $4^{\text {th }}$ period at a Higher Education Institution built infographics, as a requirement for the practical content of the Aging Process module. The static-type infographic was adopted, following criteria such as the definition of the target audience; definition of the objective; choice of topic; selection of the most relevant information (focus); direct and accessible language; organized information; choices of color palettes and style and; infographic sketch. The entire creation process was supervised by the teacher in charge of the project, and evaluation criteria were previously established. Results: The class was divided into seven groups, resulting in the production of an infographic with a specific topic per group. The human aging topics were: Degenerative Joint Diseases, Bone Weakness, Pneumonia in the Elderly, Acute Myocardial Infarction, Vascular Dementia, Atherosclerosis and Herpes Zoster. It is worth noting that in addition to the creation, each group presented the final product to the other colleagues, explaining each item included in the static infographic. Conclusions: We observed that the students satisfactorily met the proposed evaluation requirements, demonstrating their involvement in the construction of infographics and, above all, in simple, creative and objective learning, using a powerful visual tool. We also add that the printed material will be used as aid in the histology laboratory and in extramural activities. 


\section{PALAVRAS-CHAVE}

- Educação Médica

- Aprendizagem Baseada em Problemas.

- Conhecimento.

- Criatividade

\section{RESUMO}

Introdução: No contexto das graduações médicas, o desenvolvimento de metodologias que estimulam a busca do aprendizado, a autonomia e a criatividade dos discentes é essencial para a formação médica no Brasil. O estudo visa descrever a construção de infográficos como proposta pedagógica para o aprendizado dos processos orgânicos do envelhecimento humano por estudantes de Medicina. Método: Os discentes do quarto período do curso de Medicina de uma instituição de ensino superior construíram infográficos como requisito de conteúdo prático do módulo "Processos de Envelhecimento". Adotou-se o infográfico do tipo estático, seguindo critérios como: definição do público-alvo; definição do objetivo; escolha do tema; seleção das informações mais relevantes (foco); linguagem direta e acessível; informações organizadas; escolhas das paletas de cores e estilo; e esboço do infográfico. Todo processo de elaboração foi supervisionado pelo docente responsável, sendo previamente estabelecidos os critérios de avaliação. Resultados: A turma foi dividida em sete grupos, resultando na produção de um infográfico com uma temática específica por grupo. Os temas do envelhecimento humano foram: doenças articulares degenerativas, enfraquecimento ósseo, pneumonia no idoso, infarto agudo do miocárdio, demência vascular, aterosclerose e herpes-zóster. É válido salientar que, além da criação, cada grupo apresentou aos demais colegas o produto final, explicitando cada item inserido no infográfico estático. Conclusões: Foi possível observar que os alunos cumpriram de forma satisfatória os requisitos avaliativos propostos, demonstrando envolvimento na construção dos infográficos e, sobretudo, no aprendizado simples, criativo e objetivo, utilizando uma poderosa ferramenta visual. Acrescenta-se também que o material impresso servirá de apoio no laboratório de histologia e em atividades extramuros.

Received on 5/19/20

Accepted on $7 / 1 / 20$

\section{INTRODUCTION}

In the area of education, much is discussed about improvements in the existing teaching practices, rethinking teacher training, reformulating curricula, aiming to promote education in which students can be active and participate in their role, developing autonomy and critical thinking in learning process ${ }^{1,2}$, in addition to the possibility of exploring the production of knowledge and the transformation of educational paradigms by strengthening creativity ${ }^{3}$. In this scenario, the teacher ceases to be the center of knowledge, becoming a mediator, an instigator in the learning process, responsible for using different resources to provide students with a constructive pedagogical strategy ${ }^{1,2}$.

In the context of medical education, the proposal to base student learning on active methodologies started to be standardized in Brazil in 2001 through the National Curricular Guidelines (NCGs) aimed at medical courses, and became mandatory in the 2014 NCGs, prioritizing the pedagogical proposals aimed at "learning to learn". Therefore, it provides a unique and active performance for each student, using individual and collective activities, developing not only theoretical knowledge, but also interpersonal relationships, reflection of contents, that is, a constant preparation for the search for knowledge $e^{4,5,6,7}$.

Nevertheless, it is beneficial to use tools that act as modifiers of the current traditional education model in society, guaranteeing the effectiveness of the methodological principles of a transformative education practice. Hence, infographics appear as an instrument to assist with this change, resulting in the commitment of all those involved in its construction process. The infographic is a tool used to synthesize the information displayed in a text. It is an explanation carried out through the association of texts and images (photography, drawings, graphics, anagrams, diagrams, among others) of which purpose is to show concise information, in an attractive, clear and objective way to the reader ${ }^{8}$. To be effective, infographics must be developed aiming at the quick reading and easy understanding of the addressed topic ${ }^{9}$.

Through infographics, students can access the most diverse types of content and that can be explored in multiple formats ${ }^{10}$, that is, it can be an alternative source of information, a source of research and a method for discussion. Thus, this resource can be a great ally for the teacher to develop pedagogical strategies for teaching, due to its dynamic character, its association between text and images that facilitates and improves the teaching-learning process and, above all, encourages students to learn in a playful way, valuing creativity, and not only productivity ${ }^{11}$. Therefore, this study aims to describe the construction of infographics as a pedagogical proposal for the learning of organic human aging processes by medical students.

\section{EXPERIENCE REPORT}

This is an experience report, carried out with students from the fourth period of the medical course at a Higher Education Institution (HEI) in the municipality of Vitória da Conquista, state of Bahia, Brazil, in the second semester of 2019, as a practical content requirement for the module called "Aging Processes". The proposal designed for the performance of practical classes was the production of infographics, of which main topic was focused on the organic processes of aging, as well as the histological, physiological and /or pathological changes arising from these processes.

Initially, the teacher in charge introduced the concept of infographics to the class, its types, usefulness, websites and free applications with different layouts, so that the groups were able to choose the best way to produce the proposed material. Such an explanation was important to overcome the difficulties posed by the students regarding the understanding of the infographic and its construction process.

REVISTA BRASILEIRA DE EDUCAÇÃO MÉDICA

2 44 (4) : e109; 2020 
A good infographic is the result of research, searches and the definition of a strategy. In this context, the students were guided 'step by step, which indicated the fundamental elements for the creation of this tool: definition of the target audience; definition of the objective; choice of topic; selection of the most relevant information (focus); direct and accessible language; organized information; choices of style and color palettes and infographic sketch ${ }^{12}$.

The static-type infographic ${ }^{3}$ was adopted, which is characterized by the combination of texts and images (photography, illustration) as a standard for the development of the topics. To address the contents, each group was able to choose a specific theme, according to the drawn topics, as shown in Chart 1, explaining the aging process of that specific organ or system, focusing on histological changes, as well as their pathophysiological alterations.

Through the proposal of the topics presented for the creation of the infographics, students were asked to guide their production based on the following elements: title and subtitle; definition; risk factors; clinical condition; diagnosis; prevention measures and treatments. Subsequently, each group was responsible for presenting their infographic to the other students in the class, detailing the aging process related to their topic, as well as the histological changes resulting from the physiological or

\begin{tabular}{|c|c|}
\hline & Chart 1 \\
Proposed and developed topics on the histological human aging \\
processes, Vitória da Conquista - BA, 2019 \\
\hline Proposed topics & Developed topics \\
\hline Cartilage aging & Degenerative joint diseases \\
\hline Bone aging & Bone weakening \\
\hline Pulmonary aging & Pneumonia in the elderly \\
\hline Cardiac aging & Acute myocardial infarction \\
\hline Central nervous system aging & Vascular dementia \\
\hline Arteriosclerosis & Atherosclerosis \\
\hline Immunosenescence & Herpes Zoster \\
\hline
\end{tabular}

Source: Elaborated by the authors.

\section{Chart 3}

Student evaluation criteria regarding the construction of infographics, Vitória da Conquista - BA, 2019.

Established criteria for the evaluation of infographics

Participation in pre-established meetings with the teacher.

Acting as an active member (development of proposed activities).

Presentation of the proposed tasks within the established deadlines.

Authorship (images and texts).

Infographic (clear, objective, coherent, reliable information; correct use of spelling; scientific language; adequate layout).

References (current and reliable).

Mastery and clarity of information in the oral presentation of the infographic.

Source: Elaborated by the authors. pathological aging process, in accordance with the previously listed criteria. This proposal aimed at promoting socialization and the sharing of all the material developed during the semester, thus favoring individual and collective reflection, as well as the learning of all the proposed topics, and not only what each group developed individually. Moreover, the final product of each produced infographic was printed in banner format and displayed at the HEI Histology Laboratory, allowing easy access and providing supporting material for all HEI students.

It is worth noting that the entire process for the infographic creation was monitored by the supervising professor from the conception, research phase, layout sketch, until completion, and each group had to attend the nine pre-scheduled meetings, according to the schedule detailed in Chart 2.

In addition to the creation stages, the teacher also established criteria for the evaluation process, as the creation of the infographics was closely associated to the practical component of the aging module. Thus, the evaluation took place in a procedural and continuous way, so that each student was individually and collectively evaluated according to the criteria established in Chart 3, also allowing the feedback to be given at the end of the process.

In total, seven infographics (Figure 1) were developed by the students, encompassing different body systems, as shown in Chart 1 ,

\begin{tabular}{|c|c|c|}
\hline $\begin{array}{r}\text { Schedule for the monitor } \\
\text { infographics, } \mathrm{V}\end{array}$ & $\begin{array}{l}\text { Chart } 2 \\
\text { f activities } d i \\
\text { a da Conquis }\end{array}$ & $\begin{array}{l}\text { the preparation of } \\
3 \mathrm{~A}, 2019 \text {. }\end{array}$ \\
\hline Activities & Groups & Meetings/Schedule \\
\hline $\begin{array}{l}\text { Brief explanation of the } \\
\text { topics to be addressed in the } \\
\text { module. }\end{array}$ & $\begin{array}{c}1,2,3 \text { and } 4 \\
5,6 \text { and } 7\end{array}$ & $\begin{array}{c}1^{\text {st }} \\
08: 00 \mathrm{am}-12: 00 \mathrm{pm} \\
2^{\text {nd }} \\
08: 00 \mathrm{am}-12: 00 \mathrm{pm}\end{array}$ \\
\hline $\begin{array}{l}\text { Presentation of the topics } \\
\text { to be addressed; division of } \\
\text { groups and organization of } \\
\text { tasks performed by them. }\end{array}$ & $1,2,3$ and 4 & $\begin{array}{c}3^{\text {rd }} \\
08: 00 \mathrm{am}-12: 00 \mathrm{pm} \\
4^{\text {th }} \\
08: 00 \mathrm{am}-12: 00 \mathrm{pm}\end{array}$ \\
\hline $\begin{array}{l}\text { Meeting with the groups: } \\
\text { presentation of the } \\
\text { infographic structure, layout, } \\
\text { and the bibliography used. }\end{array}$ & $\begin{array}{c}1,2,3 \text { and } 4 \\
5,6 \text { and } 7\end{array}$ & $\begin{array}{c}5^{\text {th }} \\
08: 00 \mathrm{am}-12: 00 \mathrm{pm} \\
6^{\text {th }} \\
08: 00 \mathrm{am}-12: 00 \mathrm{pm}\end{array}$ \\
\hline $\begin{array}{l}\text { Meeting with the groups: } \\
\text { final structure of the } \\
\text { infographics. }\end{array}$ & $\begin{array}{l}1,2,3 \text { and } 4 \\
5,6 \text { and } 7\end{array}$ & $\begin{array}{c}7^{\text {th }} \\
08: 00 \mathrm{am}-10: 00 \mathrm{am} \\
8^{\text {th }} \\
10: 00 \mathrm{am}-12: 00 \mathrm{pm}\end{array}$ \\
\hline $\begin{array}{l}\text { Presentation of infographics } \\
\text { by group. }\end{array}$ & All & $\begin{array}{c}9^{\text {th }} \\
07: 00 \mathrm{pm}-10: 00 \mathrm{pm}\end{array}$ \\
\hline
\end{tabular}

Source: Elaborated by the authors. 


\section{Figure 1}

Thematic infographics produced by the medical students, about the organic aging process and associated pathologies, Vitória da Conquista - BA, 2019.

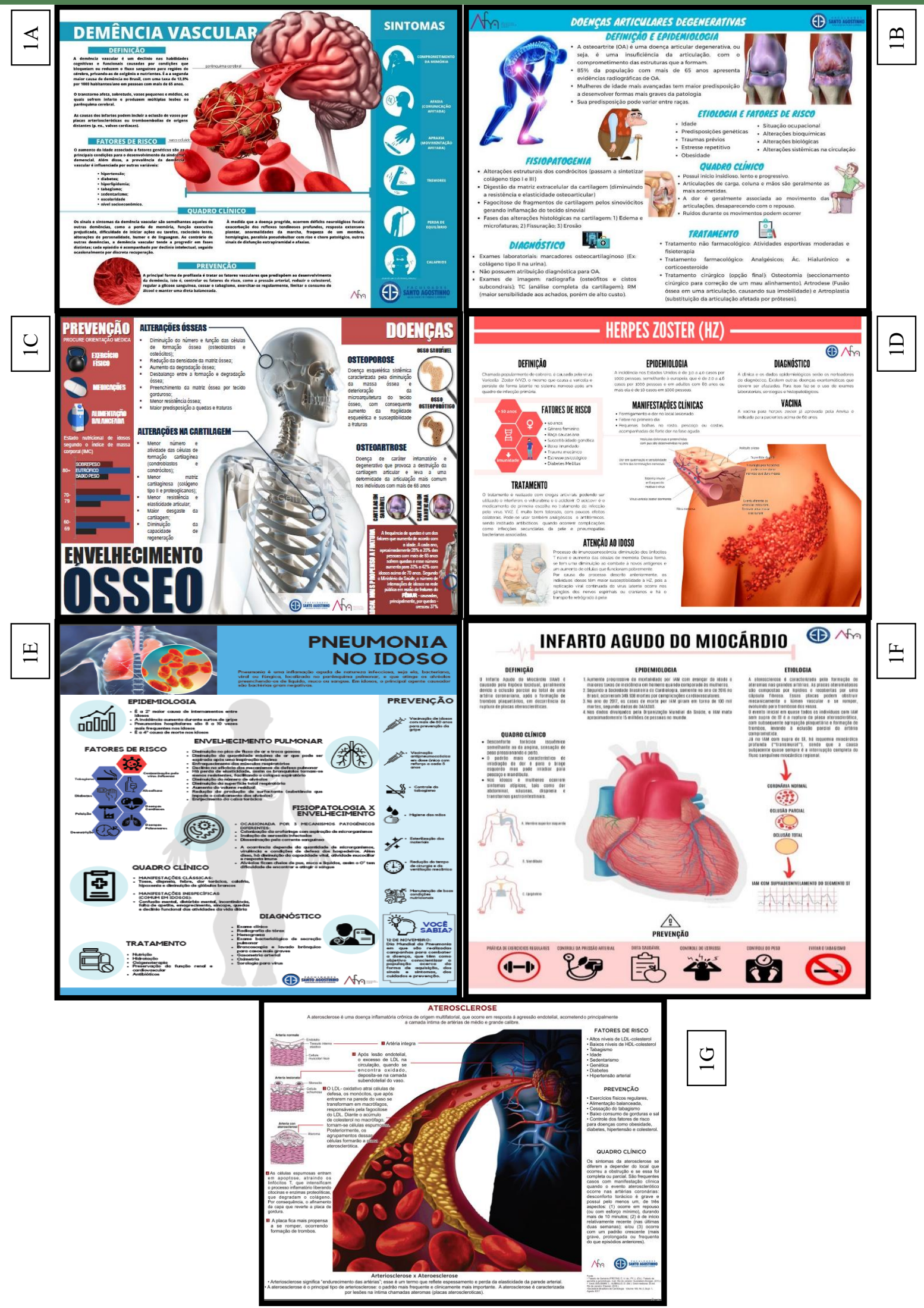

Legend: 1A - Infographic on the Central Nervous System Aging (Vascular Dementia); 1B - Infographic on Cartilage Aging (Degenerative Joint Diseases); 1C - Infographic on Bone Aging (Bone Weakening); 1D - Infographic on Immunosenescence (Herpes Zoster); 1E - Infographic on Pulmonary Aging (Pneumonia in the Elderly); 1F - Infographic on Cardiac Aging (Acute Myocardial Infarction) and 1G - Infographic on Arteriosclerosis (Atherosclerosis). 
allowing a global view of the aging process, from the understanding of the pathophysiology, risk factors, presentation of clinical signs and symptoms and treatment measures up to the preventive approaches that are taught in Health Education.

The choice of the infographic as a tool that facilitates the teachinglearning process was made aiming at exploring its potential, among which are: a) The follow-up of each stage of the creation process, providing monitoring of the student's learning process since it explored, when necessary, each step in the construction of the infographic; b) Development of cognitive skills, such as interpretation, analysis and synthesis; c) Encouragement of the participation in the meetings for the construction of the infographic, due to its dynamic, attractive and objective aspects, stimulating the sense of responsibility, leadership and teamwork; d) Development of a new observation perspective, so that students could perceive fundamental aspects of the addressed topic, considering the problem proposed within its magnitude; e) Possibility of associating different technological resources in the construction of the infographic, in addition to the development of information exposure strategies, which are essential for the routine of a health professional'.

As discussed above, infographics represent a tool that makes it possible, during their construction, for students to develop different ways to express their understanding of the worked topic. The multifaceted character can show several possibilities when it is being structured, as each individual has a specific viewpoint and correlates it according to their interpretation ${ }^{3}$. Therefore, it can be observed that the students met the requirements established for the proposed evaluation criteria, demonstrating their involvement with the creation of the material and, although we observed difficulty regarding the setting up of the work groups, this limitation was overcome and work skills were developed as a team.

The literature points to the infographic as a potent active methodology tool, so that students can build knowledge in a creative and informative way, through visual graphic communication ${ }^{3,10}$. Also, it allows an assessment of the student in a technical and continuous way. Finally, it is worth mentioning that the present report depicts this tool as an evaluation device that encompasses the assessed subject in all their dimensions.

\section{FINAL CONSIDERATIONS}

Infographics were successfully used as tools to build the knowledge of medical students, as they allowed individual and collective learning, creativity, reflection, objectivity and the use of graphic language to understand the organic processes of aging.

In addition to the knowledge the students who prepared the infographics acquired, their final product will serve as an instrument for the acquisition of objective knowledge for the students who will attend the histology laboratory, and they can also be used outside the academic scenario, allowing the dissemination of information through this tool and academic production.

The importance of infographics as a practical evaluation device, working as an alternative tool for the evaluation process is also emphasized, since in this model, the evaluation takes place in a procedural and continuous way, taking into account the different characteristics and skills involved and developed by each student.

\section{REFERENCES}

1. Cezar PHN, Guimarães FT, Gomes AP, Rôças G, Siqueira-Batista R. Transição paradigmática na educação médica: um olhar construtivista dirigido à aprendizagem baseada em problemas. Rev Bras Educ Med. 2010;34(2):298-303.

2. Bedin FC, Kiouranis NMM, Sari ERG, Brustolin LC. Construção de infográficos como uma ferramenta potencializadora do educar pela pesquisa. Arquivos do Mudi. 2017;21(3):26-37.

3. Bottentuit Júnior JB, Mendes AGLM, Da Silva NM. O uso do infográfico em sala de aula: uma experiência na disciplina de literatura. Revista Educa. 2017;11(3)105-27.

4. Brasil. Ministério da Educação. Conselho Nacional de Educação. Câmara de Educação Superior. Resolução no CNE/CES 4/2001. Institui Diretrizes Curriculares Nacionais do Curso de Graduação em Medicina. Diário Oficial da União Brasília, 9 nov 2001; Seção 1, p. 38.

5. Brasil. Ministério da Educação. Conselho Nacional de Educação. Câmara da Educação Superior. Resolução nº CNE/CES 3/2014. Institui Diretrizes Curriculares Nacionais do Curso de Graduação em Medicina e dá outras providências. Diário Oficial da União Brasília, 23 jun 2014; Seção 1, p. 8-11.

6. Franco CAGS, Cubas MR, Franco RS. Currículo de medicina e as competências propostas pelas diretrizes curriculares. Rev Bras Educ Med. 2014;38(2):221-30.

7. Rocha VXM. Reformas na educação médica no Brasil: estudo comparativo entre as diretrizes curriculares nacionais dos cursos de graduação em medicina de 2001 e 2014 [dissertação]. Santos: Universidade Católica de Santos; 2017.

8. Pedroza NP, Bezerra EP, Nicolau MA. Ferramentas para elaboração de infográficos: um estudo de caso. Anais do X Encontro Virtual de Documentação em Software Livre e VII Congresso Internacional de Linguagem e Tecnologia Online; 2013 nov. 11-13; Belo Horizonte, Brasil. Belo Horizonte: UFMG; 2013. p. 1-8.

9. Lyra KT, Oliveira RNB, Reis RCD, Cruz WM, Nakagawa EY, Isotani S. Infográficos versus materiais de aprendizagem tradicionais: uma investigação empírica. Renote. 2016;14(2):1-12.

10. Bottentuitt Júnior JB, Lisboa ES, Coutinho CP. O infográfico e as suas potencialidades educacionais. Quaestio - Revista de Estudos em Educação. 2011;13(2):163-83.

11. Pinto CL, Tavares HM. O lúdico na aprendizagem: apreender e aprender. Revista da Católica. 2010;2(3):226-35.

12. Nogueira A. Crie o seu infográfico com essas ferramentas gratuitas! Hotmart; 2019 [acesso em 7 fev 2020]. Disponível em: https://blog. hotmart.com/pt-br/como-fazer-um-infografico/.

\section{AUTHORS' CONTRIBUTION}

Diêgo Andrade de Oliveira created the project and is the professor in charge of the intervention, participated in the planning, scientific construction, performance, analysis, writing and final version of the manuscript. Rosângela Souza Lessa contributed to the intervention idea proposal, creation, writing, discussion of the report and revision of the final version of the manuscript. Suzana Cristina Silva Ribeiro contributed to the analysis, writing and review of the final draft of the manuscript. Pedro Fonseca de Vasconcelos contributed to the intervention idea

$5 \mid$\begin{tabular}{l|l} 
REVISTA BRASILEIRA DE EDUCAÇÃO MÉDICA \\
\hline 44 (4) : e109; 2020
\end{tabular} 
proposal, creation, writing, discussion of the report and review of the final version of the manuscript.

\section{CONFLICTS OF INTEREST}

The authors declare no conflicts of interest.

\section{ADDRESS FOR CORRESPONDENCE}

Diêgo Andrade de Oliveira. Faculdades Santo Agostinho, Avenida Olívia Flores, 200, Candeias, Vitória da Conquista, BA, Brasil. CEP: 45028-100.

E-mail: diego.andrade@fasa.edu.br 